\title{
The right to life - a fundamental human right
}

\author{
Associate Professor PhD. Luminita Dragne \\ "Dimitrie Cantemir" Christian University \\ Faculty of Legal and Administrative Sciences
}

\begin{abstract}
The right to life belongs to the category of human rights, which are inalienable and imprescriptible rights which are inherent to all human beings. By virtue of the right to life, any human being enjoys all the other rights prescribed and guaranteed by the constitution and by the international documents. In The Universal Declaration of Human Rights, the most important document adopted by the General Assembly of the United Nations shortly after the end of the Second World War, it is stipulated that "Everyone has the right to life, liberty and security of person"(art. 3). The enshrinement of the right to life in the Constitution, the fundamental law of the state, confers a fundamental character as it is the core of the fundamental human rights.
\end{abstract}

\section{Introduction}

In general, human rights are defined as "the prerogatives conferred in the domestic law and which are recognized by the international law to each individual, in his relation with the community and the state, which express the fundamental social values and are meant to satisfy the essential human needs and lawful endeavours, in the economic, social, political, cultural and historical context of a certain society" (Nastase, 1992).

Human rights are a constant concern for the international community, which materialised in numerous legal instruments adopted both at a global, and a regional level over the years.

The expression human rights refers to the inalienable and imprescriptible rights of the human being.

From the wide sphere of the rights a person has, it is only certain rights which are fundamental. The distinction between fundamental rights and the other subjective rights is done according to two criteria: a) their importance for the individual, the citizen and b) their importance for the state. Thus, we could say that fundamental rights are those subjective rights which belong to the citizens and are essential for their life, liberty, dignity and freedom, indispensable for the free development of human personality, the rights which are enshrined in the Constitution and are warranted by the Constitution and the laws (Muraru, 1995).

The right to life belongs to the category of fundamental rights and, from a historical perspective, it is one of the first rights proclaimed and enshrined in international law. 


\section{International law}

The first document adopted by the General Assembly of the United Nations, shortly after the end of the Second World War, is The Universal Declaration of Human Rights ${ }^{1}$ which proclaims that all human beings are born free and equal in dignity and rights (art. 1). It is thus established a common ideal that is to be accomplished by all the states in the world.

The Universal Declaration of Human Rights gives a new sense, and a particular force to human rights, and, moreover, to their legal protection. The Universal Declaration of Human Rights speaks about a common conception, a common ideal. The Universal Declaration of Human Rights has rallied and engaged the international community since. By means of this Declaration, the proclamation and guarantee of human liberties emerge from the narrow frontiers of the state, and become a problem of the international community, a problem for the whole world (Muraru, 1994).

With regard to the right to life, in the Declaration, it is noted that everyone has the right to life, liberty and security of person (art. 3), and the International Covenant on Civil and Political Rights ${ }^{2}$ contains provisions with regard to the right to life, prohibition of torture, slavery, the right to freedom and personal security, as well as other rights and liberties.

The UN General Assembly adopted, in 1989, the Second Optional Protocol to the International Covenant on Civil and Political Rights, aiming at the abolition of the death penalty, considering that these provisions would "contribute to enhancement of human dignity and progressive development of human rights".

Article 2 of this Protocol provides for the only exception allowed, which is "the application of the death penalty in time of war pursuant to a conviction for a most serious crime of a military nature committed during wartime", if a reservation was made at the time of ratification or accession.

Other international documents meant to enshrine and ensure the protection of the right to life were adopted by the states, of which we wish to mention Convention on the Prevention and Punishment of the Crime of Genocide, adopted by the UN General Assembly on 9 December 1948 and which entered into force on 12 January 1951.

This document declares that genocide is a crime against humanity, and it is defined, in art. II, as "any of the following acts committed with intent to destroy, in whole or in part, a national, ethnical, racial or religious group, as such: (a) Killing members of the group; (b) Causing serious bodily or mental harm to members of the group; (c) Deliberately inflicting on the group conditions of life calculated to bring about its physical destruction in whole or in part; (d) Imposing measures intended to prevent births within the group; (e) Forcibly transferring children of the group to another group."

The Convention stipulates that not only the acts of genocide are to be punished, but also the conspiracy; the direct and public incitement and the attempt to commit genocide, as well as the complicity in genocide.

\footnotetext{
${ }^{1}$ The Universal Declaration of Human Rights was adopted by the UN General Assembly on 10 December 1948.

${ }^{2}$ The Covenant was adopted by the UN General Assembly on 16 December 1966 and it entered into force on 23 March 1976. 66
} 
Another important document is the Convention on the Non-Applicability of Statutory Limitations to War Crimes and Crimes Against Humanity, which was adopted by the UN General Assembly on 26 November 1968 and entered into force on 11 November 1970. This Convention declares that war crimes and crimes against humanity are imprescriptible, as they are among the gravest crimes in international law.

The International Convention on the Suppression and Punishment of the Crime of Apartheid was adopted by the UN General Assembly on 30 November 1973 and entered into force on 18 July 1976. This convention declares that the apartheid is a crime against humanity and that inhuman acts resulting from the policies and practices of apartheid and similar policies and practices of racial segregation and discrimination, are crimes violating the principles of international law, and organisations, institutions and persons that commit such acts are to be considered criminal. The states parties to this convention engage to take the necessary measures in order to prevent the enactment of such acts and to punish those who are guilty of such acts.

Another instrument of outmost importance is the Convention against Torture and Other Cruel, Inhuman or Degrading Treatment or Punishment which was adopted by the UN General Assembly on 10 December 1984. The Convention establishes a series of obligations on behalf of the states parties: to forbid and punish the commitment of acts of tortures and the complicity to the enactment of such acts, to punish those who do such acts and to extradite them, accordingly.

At an European level, one of the most important documents adopted is the European Convention on Human Rights and Fundamental Freedoms ${ }^{3}$, a treaty by virtue of which the signatory states intended to protect the fundamental rights and liberties enshrined in the Universal Declaration on Human Rights, as approved by the UN General Assembly on 10 December 1948.

According to article 2, alignment 1 of the European Convention, the right to life of everyone is protected by the law. Further on, with regard to the sentence to death, the Convention establishes the situation in which the right to life can be attained as a result of the execution of a capital sentence of a court following the conviction of a crime for which this penalty is provided by law.

In the 2nd alignment of the same article, it is stipulated that „Deprivation of life shall not be regarded as inflicted in contravention of this Article when it results from the use of force which is no more than absolutely necessary: (a) in defence of any person from unlawful violence; (b) in order to effect a lawful arrest or to prevent the escape of a person lawfully detained; (c) in action lawfully taken for the purpose of quelling a riot or insurrection". In article 3, it is provided that "No one shall be subjected to torture or to inhuman or degrading treatment or punishment."

The abolishment of the death penalty is definitely made by means of the Protocole no. 6 to the Convention, which establishes in its article 1 that: „The death penalty shall be abolished. No-one shall be condemned to such penalty or executed." Article 3 stipulates an exception: "A State may make provision in its

\footnotetext{
${ }^{3}$ Adopted in Rome, in the year 1950, and entered into force on 3 September 1953, the Convention was elaborated by the Council of Europe, ratified by all member states and establishes a control mechanism on human rights for the signatory states. Over the years, it was completed with 13 additional protocols and it became a part of the legal system of most of the states party to the Convention.
} 
law for the death penalty in respect of acts committed in time of war or of imminent threat of war; such penalty shall be applied only in the instances laid down in the law and in accordance with its provisions. The State shall communicate to the Secretary General of the Council of Europe the relevant provisions of that law."

Subsequently, on 3 May 2002, in Vilnius, the Member States of the Council of Europe elaborated the Protocol no. $13^{4}$ to the European Convention on Human Rights and Fundamental Freedoms, concerning the abolition of the death penalty in all circumstances, as an expression of their conviction that everyone's right to life, as mentioned in the Preamble, is a basic value in a democratic society and that the abolition of the death penalty is essential for the protection of this right and for the full recognition of the inherent dignity of all human beings, wishing to strengthen the protection of the right to life guaranteed by the Convention, and noting that Protocol No. 6 to the Convention, concerning the Abolition of the Death Penalty, signed at Strasbourg on 28 April 1983, did not exclude the death penalty in respect of acts committed in time of war or of imminent threat of war.

Thus, in article 1 of the Protocole, it is stipulated that „The death penalty shall be abolished. No one shall be condemned to such penalty or executed." In the next article, it is specified that no derogation from the provisions of this Protocol shall be made under Article 15 of the Convention. The Convention also stipulates in article 3 that "No reservation may be made under Article 57 of the Convention in respect of the provisions of this Protocol."

The Charter of Fundamental Rights of the European Union disposes, in article 2, that "Everyone has the right to life. No one shall be condemned to the death penalty, or executed."

\section{The right to life - a Constitutional right}

Every Constitution of the world includes fundamental rules and principles which are essential for the society and for the citizen, including those regarding to the fundamental human rights and freedoms. The centre of these rights and freedoms is the right to life, an absolute right of every human being.

By virtue of the right to life, individuals rejoice all the other rights and freedoms, as stipulated and warranted by the fundamental law. Their enshrinement in the Constitution is the proof of the fact that the fundamental right to life is protected by the state by means of specific mechanisms.

The protection of the right to life compels states ${ }^{5}$ not only to refrain from the intentional causation of death of a person, but also inflicts the positive obligation to take appropriate measures in order to ensure the effective protection of the life of every human being.

\footnotetext{
${ }^{4}$ The Protocol was opened for signature on the same day. Romania ratified this Protocol by the Law no. 7/2003, published in the Official Journal of Romania, Part I, no. 27 of 20 January 2003.

${ }^{5}$ European Commission on Human Rights, Widmer vs. Switzerland Decision of 10.02.1993, The constitutional right to life and the Penal Code - http://comparat.tripod.com/articolero/viata.pdf 
The Constitution of Romania, in article 22 alignment 1, disposes that ,the right to life, as well as the right to physical and psychical integrity of the person are guaranteed" 6 , and, in alignment 2 , it is indicated that „no one can be subject to torture or any other punishment or inhuman or degrading treatment. Any act that touches upon the right to life is incriminated, according to the dispositions of the penal law.

Furthermore, in alignment 3 of the same article, it is provided that the death penalty is forbidden. This disposition is absolute, as there is no exception admitted.

An important principle enshrined in the Romanian Constitution, in article 20, is the priority of the international law, according to which constitutional dispositions concerning citizens' rights and liberties will be interpreted and enforced in agreement with the Universal Declaration on Human Rights, with the covenants and other treaties Romania is a party to.

The above mentioned disposition enshrines, with regard to human rights, the rule regarding the priority of international law in its relation with domestic law.

As a result of the constitutional reform in 2003, the Constitution was amended, an exception to the rule being established: when any inconsistencies exist between the covenants and treaties on the fundamental rights Romania is a party to, and the national laws, the internal regulations shall take precedence, unless the Constitution or national laws comprise more favourable provisions.

Thus, if there are inconsistencies between the pact and treaties concerning the fundamental human rights to which Romania is a part of, and the internal laws, the international regulations prevail, except when domestic laws provide for more favourable dispositions

\section{Conclusions}

Compliance with the fundamental rights and freedoms is one of the most important problems of the new international order.

As the Preamble to the Universal Declaration on Human Rights highlights recognition of the inherent dignity and of the equal and inalienable rights of all members of the human family is the foundation of freedom, justice and peace in the world.

Generally, Conventions are not destined to replace the domestic systems of protection of human rights, but to establish an international guarantee, so that human rights protection is done effectively at a national level. "It's neither by the violence of weapons, nor by the dictatorship of economy that we will make the world

\footnotetext{
${ }^{6}$ In Romania, the death penalty was abolished by the Decree-law no. 6/1990. This Decree substituted the death penalty, which was previously provided for certain infractions in the Penal Code and special laws. "The interdiction to apply the death penalty allowed Romania to ratify the Second Optional Protocol to the International Covenant on Civil and Political Rights on the abolishment of the death penalty (by the Law no 7/1991, published in the Official Journal no. 18 of 26 January 1991.)"- M. Bădescu, Constitutional Law and Political Institutions, Universul Juridic Publishing House, Bucharest, 2012, p. 120
} 
progress toward a more lawful international order, but by the emergence and the recognition of an universal international law, and by its most necessary and natural prolongation: an universal justice" (Leclerc, 1997).

Unfortunately, in the past few years, we assisted at a series of cases of infringement of these rights, most of them being the performed by the authorities of the state, as it can be noticed in the numerous complaints addressed to the European Court on Human Rights. An important role in this sombre statistics is played by the causes in which the right to life was violated.

In order to ensure an effective protection, and, also, in order to reduce all facts that could lead to the violation of the right to life, states, the only entities having the appropriate means to do it, should reconsider this policy and should adopt efficient means of protection of this right. If these lack, the right to life remains a mere abstract theory in many cases.

\section{References}

M. Bădescu, 2012, Constitutional Law and Political Institutions, Universul Juridic Publishing House, Bucharest Henri Leclerc, 1997, Un combat par justice, Edition La Découverte, in Chantal Méral, Les Tribunaux Français face à la justice européenne. Les clés d'un contre-pouvoir, ed. Filipacchi

I.Muraru, 1995, Constitutional law and political institutions, Volume I, Actami Publishing House, Bucharest I. Muraru, 1994, The Topical Interest of The Universal Declaration of Human Rights, in Human Rights Quarterly, I.R.D.O., Year IV, no. 4/1994

Adrian Năstase, 1992, Human Rights, the religion of the end of the century, I.R.D.O., Bucharest

European Commission on Human Rights, Widmer vs. Switzerland Decision of 10.02.1993, The constitutional right to life and the Penal Code - http://comparat.tripod.com/articolero/viata.pdf

The Universal Declaration of Human Rights was adopted by the UN General Assembly on 10 December 1948 The Universal Declaration of Human Rights was adopted by the UN General Assembly on 10 December 1948. The Covenant was adopted by the UN General Assembly on 16 December 1966 and it entered into force on 23 March 1976. 